\title{
Öğretmen Adaylarının Eğitim Hukuku İle İlgili Eğitim İhtiyaçlarının Belirlenmesi ${ }^{1}$
}

\author{
DOI: 10.26466/opus.594809 \\ * \\ Müzeyyen Övür* - Faruk Levent** \\ * Doktora Öğrencisi, Marmara Üniversitesi, Eğitim Bilimleri Ens., Kadıköy / İstanbul / Türkiye \\ E-Posta: muzeyyendonmez@gmail.com \\ ORCID: $\underline{0000-0003-4327-6456}$ \\ ** Doç. Dr, Marmara Üniversitesi, Atatürk Eğitim Fakültesi, Kadıköy / İstanbul / Türkiye \\ E-Posta: faruk.levent@marmara.edu.tr \\ ORCID: $\underline{0000-0003-3429-6666}$
}

Öz

Bu araştırmanın amacı öğretmen adaylarının temel düzeyde eğitim hukuku ile ilgili eğitim ihtiyaçlarının neler olduğunu belirlemektir. Bu çalışmada, nicel araştırma yöntemlerinden tarama modeli kullanılmıştır. Araştırmanın örneklem grubunu Marmara Üniversitesi'nde eğitim görmekte olan, "Ĕ̆gitim Yönetimi" veya "Türk Ĕ̆itim Sistemi ve Okul Yönetimi" derslerini almış olan 3. ve 4. simı öğrencisi 386 öğretmen adayı oluşturmuştur. Veri toplama aracı olarak öğretmen adaylarının temel düzeyde eğitim hukuku ile ilgili bilgi düzeylerini belirlemek için araştırmacılar tarafından 54 soruluk "Eğitim Hukukuna İlişkin Bilgi Düzeyi Belirleme Anketi" oluşturulmuştur. Toplanan verilerin çözümlenmesinde yüzde, frekans ve aritmetik ortalama testleri yapılmıştır. Elde edilen bulgulara göre; geliştirilen formda yer alan "öğretmenlerin hak ve sorumlulukları", "disiplin hukuku", "özel öğretim hukuku", "özel eğitim hukuku” ve "kamu okullarımin finansmanı" ile ilgili bölümlerdeki sorulara verilen doğru cevapların ortalamalarının düşük olduğu saptanmıştır. "Öğrencilerin hak ve sorumlulukları" ve "sinav hukuku" ile ilgili bölümlerinde bulunan sorulara verilen doğru cevapların ortalamalarımın ise yüksek olduğu ancak "eğitim alma hakkı" ve "eğitime devamin sağlanması", "öğrencilerin kılık kıyafetleri" ve "sınav kağıtlarının hazırlanması" ile ilgili sorulara verilen doğru cevaplarm ortalamalarmnn ise düşük olduğu tespit edilmiştir. Bu araşttrmada elde edilen sonuçlar doğrultusunda ö̆gretmen adaylarının eğitim hukuku ile ilgili eğitim ihtiyaçlarının giderilmesine yönelik Eğitim Hukuku dersinin lisans düzeyinde zorunlu ders olarak müfredata alınmast önerilmektedir. Böylece öğretmen adaylarının bu alanda görülen bilgi eksiklikleri giderilerek, meslek hayatlarında karşılarına çıkabilecek farklı durumlarla mücadele edebilme becerileri kazandırlabilir.

Anahtar Kelimeler: Ĕ̆itim hukuku, öğretmen adayı, eğitim ihtiyacı

\footnotetext{
${ }^{1}$ Bu çalışma, Müzeyyen ÖVÜR tarafından Doç. Dr. Faruk Levent danışmanlığında tamamlanan doktora tezinin bir bölümünden üretilmiştir.
} 


\title{
Determination of the Educational Needs of Teacher Candidates Related to Educational Law
}

\begin{abstract}
The purpose of this study was to determine the educational needs of teacher candidates related about basic education law. In this study, screening model which is one of the quantitative research methods was used. The sample group of the study consisted of 386 teacher candidates from $3 r d$ and 4th grade students who are studying at Marmara University and who took "Education Management" or "Turkish Education System and School Management" courses. As a data collection tool, 54-item Knowledge Level Determination Questionnaire on Educational Law tarafindan was prepared by the researchers to determine the level of knowledge of prospective teachers about basic education law. Percentage, frequency and arithmetic mean tests were performed to analyze the collected data. According to the findings; "Rights And Responsibilities Of Teachers", "Disciplinary Law", "Private Teaching Law" "Special Education Law" and "Financing Public Schools" It was found that the average of the correct answers given to the questions in the related sections were low. Rights And Responsibilities Of Students" and "Exam Law" it was found that the average of the correct answers to the questions found in the relevant sections of the study was high. But "Right to Education" "Ensuring Continuation of Education", "Students' Costumes" and "Preparation of Examination Papers" it was found that the average of the correct answers to the questions about the low. In line with the results obtained in this study, it is suggested that the Education Law course should be included in the curriculum as a compulsory course at the undergraduate level in order to meet the educational needs of prospective teachers regarding education law. Thus, by eliminating the information deficiencies of the prospective teachers in this field, they can gain the skills to combat different situations in their professional lives.
\end{abstract}

Keywords Educational law, teacher candidates, educational needs 


\section{Giriş}

Eğitimin herkes için zorunlu ve parasız olması benimsenmesiyle eğitim ihtiyacı devlet tarafından karşılanmaya başlanmış ve bu durum uluslararası sözleşmeler ile garanti altına alınmıştır. Herkesin eğitim hakkından faydalandırılabilmesi için dünyanın birçok yerinde ulusal ve uluslararası düzeyde çeşitli yasal düzenlemeler yapılmasının sebebi de budur. Hem eğitimi hem hukuku ilgilendiren bu düzenlemeler "Eğitim Hukuku" adında yeni bir bilim dalının ortaya çımasına zemin hazırlamıştır (Okçu, 2007).

Ülkemizde eğitim hukuku ile ilgili olarak en eski tanımlardan biri Akyüz (1981)'e aittir. Bu tanıma göre eğitim hukuku "özellikle örgün eğitim kurumlarının organizasyonu, hukuki durumu, temel yapısı, yönetim biçimi, organları arasındaki ilişkileri, bunlarm temel hak ve görevlerini, öğretmen, öğrenci gibi doğrudan doğruya okul içinde, içinde bulunmakla beraber veli gibi okulla ilişkisi olan kişilerin hukuki durumlarım düzenleyen kuralların tümü" olarak ifade edilmiştir (s.38).

Çiftçi (1993) ise eğitim hukukunu "bütün bu kurumlarda yapılan eğitimi düzenleyen hukuk kurallarmı bilimsel metodlarla inceleyen, sistemli olarak açıklayan hukuk bilimi dalıdır" şeklinde tanımlamıştır (s.32).

Bingöl (2012) çalışmasında eğitim hukuku teorisinin gerekliliği üzerine "Ĕ̆itim hukuku, kendi içlerinde ayrı birer sistem olan okul hukuku, kütüphanecilik ve bilgi paylaşımına ilişkin yasal düzenlemeler, sinav hukuku, yükseköğretim hukuku, okullarm finansmanı, okul yönetimi, öğrencilerin hak ve sorumluluklarl, yükseköğretimin finansmanı gibi kendi içerisinde çeşitlenen alanları, bütünsellik arz eden temel bir çatı altında toplayabilecek ve bu alana özgü genel ilkeler geliştirilmesinin önünü açabilecektir" diyerek konunun önemine dikkat çekmiştir (s.29).

$A B D$ ve İngiltere gibi ülkelerde eğitim hukuku ve eğitim hukukunun uzantısı olan okul hukuku alanında hem çok sayıda eser üretilmiş hem de alanla ilgili dava örneklerine ve hukuksal sorun niteliğindeki örnek olaylara değinilmiştir (Karaman Kepenekçi ve Taşkın, 2017). Amerika'da eğitim hukuku, federal ve devlet anayasa hükümlerini, federal ve eyalet tüzük ve yönetmeliklerini, sayısız yerel ilçe ve okul politikalarını ve bir dizi ortak hukuk ilkeleri ile doktrinlerini içermektedir (Imber, Geel, Blokhuis ve Feldman, 2013). Yakın zamanlarda ABD'de eğitim yöneticisi 
yetiştirmeye yönelik lisans üstü programların bilgi temelleri zaman içinde farklı akımlardan etkilenmiş ve "yönetim teorisi, liderlik, eğitim hukuku, karar verme, okul bölgesi yönetimi, işletme finans ve bütçesi, örgüt geliştirme, okul toplum ilişkileri" gibi konular da bu programlarda yer almaya başlamıştır (Şişman ve Turan, 2002).

Dünyaca ünlü Harvard Üniversitesi'nin eğitim programları incelendiğinde, "Eğitim Hukuku ve Politikası" dersi kapsamında okul finans davaları da dahil olmak üzere Amerikan ilk ve orta öğretimdeki çeşitli çağdaş yasal ve politika konularının incelendiği görülmektedir (Ahearn ve Powers, 2014). Yine Georgetown Üniversitesi'nin resmi internet sitesinde bu alanla ilgili olarak eğitim hukuku uzmanlarının; okul idaresi, öğrenci kayıtları, toplu pazarlık ve öğrenci disiplini gibi konularda yerel okul bölgelerinde çalışabileceği belirtilmiştir (Georgetown Üniversitesi, 2019).

Türkiye'de 2018-2019 öğretim yılında uygulamaya konulan “Öğretmen Yetiştirme Programı" çerçevesinde öğretmen olmaya karar veren ve Eğitim Fakültesinde okuyan öğretmen adaylarına, "Eğitim Hukuku" dersi aracılığıyla temel hukuk bilgilerin verilmesi öngörülmüştür (YÖK, 2018a). $\mathrm{Bu}$ dersle, öğrencilerin eğitim hukuku konusunda bilgi ve becerilerini geliştirmeleri ve bunları meslek hayatlarına yansıtmaları amaçlanmaktadır. Bu bağlamda araştırmanın problem cümlesi; "öğretmen adaylarının temel düzeyde eğitim hukuku ile ilgili eğitim ihtiyaçları nelerdir?" şeklindedir.

\section{Yöntem}

\section{Araştırmanın Modeli}

Araştırmada nicel araştırma yöntemlerinden olan tarama deseni kullanılmıştır. Creswel (2017)'e göre tarama deseniyle; bir evrenden seçilmiş bir örneklem üzerinde çalışmalar yapılarak "evren genelindeki eğilim, tutum veya görüşlerin nicel veya numeric olarak betimlenmesi" sağlanır. 


\section{Örneklem Grubu}

Araştırmanın evrenini, Marmara Üniversitesi Atatürk Eğitim Fakültesinde eğitim görmekte olan yaklaşık 7000 öğretmen adayı oluşturmaktadır. Örneklem seçiminde amaçlı örnekleme yöntemlerinden ölçüt örnekleme tekniği kullanılmıştır. Yıldırım ve Şimşek (2011)'e göre bu yöntem ile önceden belirlenmiş bir dizi ölçütü karşılayan bütün durumlar çalışılır (s.112). Bu araştırmadaki ölçütler; 3. veya 4. sınıf öğrencisi olma ve "Eğitim Yönetimi" veya "Türk Eğitim Sistemi ve Okul Yönetimi derslerini almış olma" olarak belirlenmiştir.

Araştırmada bu ölçütlerin şart koşulmasının sebebi bahsi geçen derslerin Eğitim Hukuku ders içeriği ile yakın bir içeriğe sahip olması ve mezun olmaya yakın öğretmen adaylarının araştırmaya dahil edilmesi isteğidir. Bu ölçütler göz önünde bulundurulduğunda örneklemi yaklaşık 450 öğretmen adayı oluşturmaktadır. Araştırma anketini ise kriterleri karşılayan 386 öğretmen adayı yanıtlamıştır. Katılımcıların demografik özelliklere göre dağılımları yüzde ve frekans değerleri Tablo 1'de gösterilmiştir.

Tablo 1'de görüldüğü üzere anketi yanıtlayan öğretmen adaylarının 268 'inin kadın, 118'inin ise erkek olduğu görülmektedir. Söz konusu rakamlar MEB 2016/2017 İstatistikleri ile karşılaştırıldığında her ikisinde de kadın sayısının daha fazla olduğu söylenebilir. MEB İstatistiklerine göre 2016-2017 eğitim-öğretim yılı sonunda resmi ve özel kurumlarda görev yapan öğretmen sayısı 989 bin 231 olarak belirlenmiştir. Öğretmenlerin yüzde $43,11^{\prime}$ i erkek, yüzde 56,89'u da kadınlardan oluşmaktadır (MEB, 2018).

Araştırmaya katılan öğretmen adaylarının \%28'i 3. Sınıf öğrencisi, \%72'si ise 4. Sınıf öğrencisidir. Böylelikle araştırmanın üst sınıf öğrencilerine uygulanma ölçütünün karşılandığı anlaşılmaktadır. Bölümlere göre dağılım incelendiğinde ise farklı bölümlerden öğretmen adaylarının ankete katılımının sağlandığı görülmektedir. Özel sektörde çalışmayı düşünen öğretmen adaylarının oranı ise \%63'tür. Yine MEB İstatistiklerine göre 2016-2017 eğitim öğretim dönemi sonunda özel kurumlarda görev yapan öğretmen sayısı 120 bin 962 olarak belirlenmiştir. Bu istatistiklere göre Milli Eğitim Bakanlı̆̆ bünyesinde görev yapmakta olan toplam öğretmen sayısının yaklaşık \%12 gibi bir bölümünü özel okullarda görev yapan 
öğretmenler oluşturmaktadır (MEB, 2018). Bu nedenle mezun olacak öğretmen adaylarının özel sektörde çalışma düşüncelerinin yüksek oranda çıkmış olması öğretmen atamalarının az sayıda olması nedeniyle normal olduğu söylenebilir.

Tablo 1. Araştırmaya Katılan Öğretmen Adaylarının Çeşitli Değişkenlere Göre Frekans ve Yüzdelik Dă̆ılımlan

\begin{tabular}{|c|c|c|}
\hline Cinsiyet & $\mathrm{f}$ & $\%$ \\
\hline Kadın & 268 & 69,4 \\
\hline Erkek & 118 & 30,6 \\
\hline Toplam & 386 & 100 \\
\hline Sinif & f & $\%$ \\
\hline 3.Sinif & 108 & 28 \\
\hline 4.Sinif & 278 & 72 \\
\hline Toplam & 386 & 100 \\
\hline Bölüm & $\mathrm{f}$ & $\%$ \\
\hline Okul Öncesi Öğr. & 32 & 8,3 \\
\hline PDR & 52 & 13,5 \\
\hline Türkçe Öğr. & 17 & 4,4 \\
\hline Sınıf Öğr. & 12 & 3,1 \\
\hline Fen Bilgisi Öğr. & 11 & 2,8 \\
\hline Matematik Öğr & 8 & 2,1 \\
\hline İngilizce Öğr & 19 & 4,9 \\
\hline Zihin Engelliler Öğr. & 93 & 24,1 \\
\hline Diğer & 142 & 36,8 \\
\hline Toplam & 386 & 100 \\
\hline Özel Sektörde Çalışma Düşüncesi & $\mathrm{f}$ & $\%$ \\
\hline Evet & 243 & 63,0 \\
\hline Hayır & 139 & 36,0 \\
\hline Cevap Yok & 4 & 1,0 \\
\hline Toplam & 386 & 100 \\
\hline
\end{tabular}

\section{Veri Toplama Aracı}

Araştırmada veri toplama aracı olarak anket formu kullanılmıştır. Veri toplama aracı araştırmacılar tarafından geliştirilmiştir. Konu ile ilgili olarak öğretmen adaylarının temel eğitim hukuku bilgisini ölçmeye yönelik geliştirilen "Eğitim Hukukuna İlişkin Bilgi Düzeyi Belirleme Anketi" iki bölümden oluşmaktadır. Birinci bölümde öğretmen adaylarının demografik özelliklerini tespit etmeye yönelik sorular bulunmaktadır. İkinci bölüm ise temel eğitim hukuku bilgilerinin tespit edilmesine 
yönelik hazırlanmış 54 sorudan oluşmaktadır. Veri toplama aracının ikinci bölümünde yer alan ifadeler öğretmen adaylarının temel eğitim hukuku bilgilerini meslek hayatı ile ilişkilendirmelerini ölçmeye yönelik olarak düzenlenmiştir. Bu amaçla literatür taraması yapılmış, Milli Eğitim Bakanlığ1 inceleme-soruşturma istatistikleri incelenmiş, 2017/2018 eğitim öğretim yılı güz dönemi boyunca öğretmen adayları ile birlikte derslere girilerek en çok hangi alanlarda soru sorduklarını tespit edebilmek için gözlemler yapılmıştır. Veri toplama aracının içerik-kapsam geçerliliği ve bilimsel doğruluğu konusunda alanında uzman öğretim üyeleri, müfettişler ve okul yöneticileri ile görüşmeler yapılarak soru formatları oluşturulmuştur. Anlaşılamayan, amaca hizmet edemeyebileceği düşünülen maddeler elenmiştir. Sorular öğretmen adaylarının seçecekleri durumlar olarak "doğru", "yanlış" ve "fikrim yok" şeklinde kapalı uçlu yargı ifadeleri şeklinde düzenlenmiştir.

Ölçüm güvenirliğini hesaplamak için SPSS 22 Paket Programı kullanılmış ve güvenirlik katsayısı (Cronbach alpha değeri) hesaplanmıştır. Cronbach alpha değeri 0,84 olarak hesaplanmış ve veri toplama aracının güvenilir olduğu anlaşılmıştır. Maddeler iki değerli [0,1] olarak ölçümlendiğinde, Kuder-Richardson 20, Cronbach'ın alfası ve Hoyt'un varyans analizi formülleri aynı sonuçları vermektedir (Bademci, 2011). Bu nedenle KR-20 katsayısının kullanılmasına gerek görülmemiştir.

\section{Verilerin Toplanması}

Verilerin toplanması işlemi elden gerçekleştirilmiştir. Anketler dağıtılmadan önce öğretmen adaylarına gerekli açıklamalar yapılmış, sorulara doğru cevap verip vermemelerinin önemli olmadığı, cevabı bilmiyorlarsa "Bilmiyorum" seçeneğini işaretlemeleri özellikle vurgulanmıştır. Anketlerin dağıtıldığ 450 öğretmen adayından 64 tanesinin anket formu (soruların eksik doldurulması nedeniyle) ayıklanarak değerlendirmeye alınmamış olup veri analizleri kriterleri karşılayan 386 öğretmen adayının anket formları üzerinden hesaplanmıştır. 


\section{Verilerin Çözümlenmesi}

Öğretmen adaylarının sürece ilişkin değerlendirmeleri frekans, yüzde ve aritmetik ortalama ile betimlenmiştir. Verilerin analizinde SPSS 22 programından faydalanılmıştır. Katılımcıların eğitim hukukuna ilişkin bilgi düzeylerini belirlemek amacıyla yapılan 54 soruluk bilgi testinde, doğru cevaplar 1 puan, yanlış cevaplar ile fikrim yok şeklinde işaretlenen cevaplar ise 0 puan olacak şekilde değerlendirilmiş ve buna göre ortalamalar hesaplanarak tablonun en alt satırında gösterilmiştir.

\section{Bulgular}

Katılımcıların temel eğitim hukuku bilgi düzeylerini belirlemek amacıyla yapılan 54 soruluk Temel Eğitim Hukuku Bilgi Testinin Öğretmenlerin Hak ve Sorumlulukları ile ilgili bölümünü 362 öğretmen adayı yanıtlamıştır. Elde edilen sonuçlar Tablo 2' de yer almaktadır:

Tablo 2. Öğretmen Adaylarının Öğretmenlerin Hak ve Sorumluluklar ile İlgili Sorulara Verdikleri Yanitlar

\begin{tabular}{|c|c|c|c|c|}
\hline \multirow{2}{*}{$\begin{array}{l}\text { Öğretmenlerin Hak ve } \\
\text { Sorumlulukları }\end{array}$} & Doğru & Yanlış & $\begin{array}{l}\text { Fikrim } \\
\text { Yok }\end{array}$ & Toplam \\
\hline & n (\%) & n (\%) & n (\%) & $\mathrm{n}$ \\
\hline $\begin{array}{l}\text { 1) Defne öğretmen doğum öncesi } 8 \text { hafta } \\
\text { doğum sonrası } 8 \text { hafta olmak üzere } 16 \\
\text { hafta analık izni kullanır. }\end{array}$ & $188(\% 49,2)$ & $40(\% 10,5)$ & $154(\% 40,3)$ & 382 \\
\hline $\begin{array}{l}\text { 2) Beş hizmet y1lını doldurmuş Raşit } \\
\text { öğretmen isterse bir yıl ücretsiz izin alır. }\end{array}$ & $78(\% 20,3)$ & $122(\% 31,8)$ & $184(\% 47,9)$ & 384 \\
\hline $\begin{array}{l}\text { 3) Doktor Levent kendisine muayeneye } \\
\text { gelen Semra ögrretmene bir seferde en } \\
\text { fazla } 10 \text { gün rapor verir. }\end{array}$ & $152(\% 39,7)$ & $85(\% 22,2)$ & $146(\% 38,1)$ & 383 \\
\hline $\begin{array}{l}\text { 4) Cengiz öğretmen görev yaptığı okulun } \\
\text { müdürünü müdür yardımcısına şikayet } \\
\text { etmelidir. }\end{array}$ & $28(\% 7,3)$ & $301(\% 78,6)$ & $54(\% 14,1)$ & 383 \\
\hline $\begin{array}{l}\text { 5) Usulüne uygun olarak istifa eden } \\
\text { Nesrin öğretmen pişman olarak } 2 \text { ay } \\
\text { sonra görevine geri dönmek istediğinde } \\
\text { bu isteği yerine getirilir. }\end{array}$ & $114(\% 29,8)$ & $126(\% 33,0)$ & $142(\% 37,2)$ & 382 \\
\hline $\begin{array}{l}\text { 6) İlk defa göreve atanan Zühtü Öğret- } \\
\text { menin yolluk alma hakkı vardır. }\end{array}$ & $201(\% 52,6)$ & $61(\% 16,00)$ & $120(\% 31,4)$ & 382 \\
\hline $\begin{array}{l}\text { 7) Aday öğretmenlere de öğretim yılına } \\
\text { hazırlık ödeneği verilir. }\end{array}$ & $151(\% 39,4)$ & $73(\% 19,1)$ & $159(\% 41,5)$ & 383 \\
\hline
\end{tabular}




\begin{tabular}{|c|c|c|c|c|}
\hline $\begin{array}{l}\text { 8) Hayatını mesleğini yapmaya adamış ve } \\
\text { sadece kamuda görev alarak çalışan Os- } \\
\text { man Öğretmen göreve başladıktan } 4 \text { yıl } \\
\text { sonra yıllık izinde kalp krizi geçirerek } \\
\text { vefat etmiştir. Ancak } 2 \text { yaşındaki kızının } \\
\text { ölüm aylığı bağlanma hakkı yoktur. }\end{array}$ & $34(\% 8,9)$ & $202(\% 52,7)$ & $147(\% 38,4)$ & 383 \\
\hline $\begin{array}{l}\text { 9) Uydurma bir suçla iftiraya uğramış } \\
\text { Feride Öğretmen soruşturma ve yar- } \\
\text { gılama sonrası aklanmı̌tır. Görev yaptığ } \\
\text { ilin valisi Feride Öğretmene merak et- } \\
\text { memesini, zaten mevzuat gereği iftirada } \\
\text { bulunanlar hakkında kamu davası açl- } \\
\text { masını Cumhuriyet Savcılığından bizzat } \\
\text { isteyeceğini belirtmiştir. }\end{array}$ & $199(\% 52,4)$ & $36(\% 9,5)$ & $145(\% 38,2)$ & 380 \\
\hline $\begin{array}{l}\text { 10) Eşi ev hanımı olan Sabri öğretmen aile } \\
\text { yardımı alamaz. }\end{array}$ & $50(\% 13,0)$ & $204(\% 53,1)$ & $130(\% 33,9)$ & 384 \\
\hline $\begin{array}{l}\text { 11) Devlet memuru olarak vefat eden Os- } \\
\text { man Öğretmenin cenazesi memleketine } \\
\text { gönderildiğinde masrafı öğretmenin eşi } \\
\text { karşılamak zorundadır. }\end{array}$ & $39(\% 10,2)$ & $143(\% 37,3)$ & $201(\% 52,5)$ & 383 \\
\hline $\begin{array}{l}\text { 12) Türkiye ve Orta Doğu Amme İdaresi } \\
\text { Enstitüsünde yüksek lisans yapan ancak } \\
\text { asıl görev yeri İstanbul olan Müzeyyen } \\
\text { Öğretmen, eğitimi süresince ücretsiz izin } \\
\text { kullanmış bu maliyete katlandığı için } \\
\text { ekonomik açıdan çok sarsılmıştır. }\end{array}$ & $114(\% 30,0)$ & $72(\% 18,9)$ & $194(\% 51,1)$ & 380 \\
\hline $\begin{array}{l}\text { 13) Serkan Öğretmen banka kredisiyle } \\
\text { ünlü bir projenin maketinden seçmiş } \\
\text { olduğu } 1+1 \text { daireyi almıştır. Dairenin ta- } \\
\text { pusu kendisine verilmediği için mal bild- } \\
\text { irimde bulunmasına gerek yoktur. }\end{array}$ & $111(\% 29,1)$ & $147(\% 38,6)$ & $123(\% 32,3)$ & 381 \\
\hline $\begin{array}{l}\text { 14) Herhangi bir sendikanın almış olduğu } \\
\text { serbest kıyafetle işe gitme eylemine sendi- } \\
\text { kasız bir memur olan Ali Öğretmen de } \\
\text { katılabilir ve göreve serbest kıyafetle } \\
\text { gidebilir. }\end{array}$ & $95(\% 25)$ & $187(\% 49,2)$ & $98(\% 25,8)$ & 380 \\
\hline $\begin{array}{l}\text { 15) Aylin Öğretmen mesai sonrası isterse } \\
\text { ikamet ettiği ilin hudutlarını izinsiz terk } \\
\text { eder. }\end{array}$ & $171(\% 45,0)$ & $131(\% 34,5)$ & $78(\% 20,5)$ & 380 \\
\hline $\begin{array}{l}\text { 16) Yüksek lisans eğitimine devam etmek } \\
\text { isteyen Merve Öğretmenin iki yarım gün } \\
\text { izin hakkı vardır. }\end{array}$ & $138(\% 36,3)$ & $44(\% 11,6)$ & $198(\% 52,1)$ & 380 \\
\hline Sorulara Verilen Yanitların Ortalaması & $\mathrm{n}$ & $\overline{\bar{X}}$ & & \\
\hline Öğretmenlerin Hak ve Sorumlulukları & 362 & 5,68 & & \\
\hline
\end{tabular}

Tablo 2' de soruların doğru şıkları renklendirilerek işaretlendirilmiştir. Öğretmen adaylarının verdiği doğru yanıtların ortalama puanının $\overline{\mathbf{X}}=\mathbf{5 , 6 8}$ olduğu, Öğretmenlerin Hak ve Sorumlulukları ile ilgili bölümde bulunan 
16 soru göz önünde bulundurulduğunda bu ortalamanın çok düşük olduğu görülmektedir. Soru içerikleri öğretmenlerin meslek hayatlarında karşılarına sık sık çıkabilecek durumlardan özenle seçildiği için öğretmenlerin bu hak ve sorumluluklarını bilmeleri çok önemlidir.

Katılımcıların temel eğitim hukuku bilgi düzeylerini belirlemek amacıyla yapılan 54 soruluk Temel Eğitim Hukuku Bilgi Testinin Öğrencilerin Hak ve Sorumlulukları ile ilgili bölümünü 365 öğretmen adayı yanıtlamıştır. Elde edilen sonuçlar Tablo 3'de yer almaktadır

Tablo 3. Öğretmen Adaylarının Öğrencilerin Hak ve Sorumluluklarn ile İlgili Sorulara Verdikleri Yanttlar

\begin{tabular}{|c|c|c|c|c|}
\hline \multirow{2}{*}{$\begin{array}{l}\text { Öğrencilerin Hak ve } \\
\text { Sorumlulukları }\end{array}$} & Doğru & Yanlış & Fikrim Yok & Toplam \\
\hline & n (\%) & n (\%) & n (\%) & $\mathrm{n}$ \\
\hline $\begin{array}{l}\text { 17) Fatma Hanım okulöncesi } \\
\text { eğitim zorunlu olduğu için her } \\
\text { yönden sağlıklı olan kızını evine } \\
\text { en yakın okula kayıt ettirmek zo- } \\
\text { rundadır. }\end{array}$ & $216(\% 57,1)$ & $107(\% 28,3)$ & $55(\% 14,6)$ & 378 \\
\hline $\begin{array}{l}\text { 18) Şehit olan Eşref Bey'in oğlu } \\
\text { memleketinde istediği ilkokula } \\
\text { nakil edilir. }\end{array}$ & $176(\% 46,4)$ & $68(\% 17,9)$ & $135(\% 35,6)$ & 379 \\
\hline $\begin{array}{l}\text { 19) Ayşe Hanım üç ay üst üste } \\
\text { aylık aidatını ödemediği için } \\
\text { anaokulunda eğitim alan oğlu- } \\
\text { nun kaydı silinir. }\end{array}$ & $65(\% 17,2)$ & $140(\% 37,1)$ & $172(\% 45,6)$ & 377 \\
\hline $\begin{array}{l}\text { 20) Mülkî amirce yapılan tebliğe } \\
\text { rağmen ilköğrenim çağındaki } \\
\text { kızını okula göndermeyen Erkin } \\
\text { Bey'e çocuğun okula devam et- } \\
\text { mediği beher gün için idarî para } \\
\text { cezası verilir. }\end{array}$ & $222(\% 59,0)$ & $42(\% 11,2)$ & $112(\% 29,8)$ & 376 \\
\hline $\begin{array}{l}\text { 21) Öğrencisinin cinsel tacize } \\
\text { uğradığın öğrenen Zeynep } \\
\text { Öğretmen, çocuğu dedikodudan } \\
\text { korumak için isterse bu durumu } \\
\text { kimseye söylemez. }\end{array}$ & $37(\% 9,8)$ & $281(\% 74,1)$ & $61(\% 16,1)$ & 379 \\
\hline $\begin{array}{l}\text { 22) İlköğrenim çağında olup da } \\
\text { mecburi ilköğretim kurumlarına } \\
\text { devam etmeyen Burak, ba- } \\
\text { basının işyerinde ücret almadan } \\
\text { çalışmasında bir sakınca yoktur. }\end{array}$ & $36(\% 9,6)$ & $272(\% 72,3)$ & $68(\% 18,1)$ & 376 \\
\hline $\begin{array}{l}\text { 23) İlkokulda uyarma yaptırımı } \\
\text { uygulanan Sezin'in velisi bu } \\
\text { yaptırıma itiraz edemez. }\end{array}$ & $73(\% 19,3)$ & $168(\% 44,4)$ & $137(\% 36,2)$ & 378 \\
\hline
\end{tabular}




\begin{tabular}{|c|c|c|c|c|}
\hline $\begin{array}{l}\text { 24) Okulun en başarılı öğrencisi } \\
\text { Orhan kınama yaptırımı alırsa } \\
\text { takdir belgesi alamaz. }\end{array}$ & $137(\% 36,2)$ & $76(\% 20,1)$ & $165(\% 43,7)$ & 378 \\
\hline $\begin{array}{l}\text { 25) Okulda } \\
\text { yürütülen soruşturma } \\
\text { kapsamında ögrencinin } \\
\text { tanık olarak ifadesine } \\
\text { başvurulacak ise mutlaka } \\
\text { rehber öğretmen de müfettişle } \\
\text { beraber hazır bulunmalıdır. }\end{array}$ & $257(\% 68,9)$ & $22(\% 5,9)$ & $94(\% 25,2)$ & 380 \\
\hline $\begin{array}{l}\text { 26) Okulöncesi ve ilkokullarda } \\
\text { kız öğrenciler baş açı derse } \\
\text { girmek zorundadırlar. Ortaokul } \\
\text { ve lisede başörtüsü takabilirler. }\end{array}$ & $142(\% 38,3)$ & $113(\% 30,5)$ & $116(\% 31,3)$ & 371 \\
\hline $\begin{array}{l}\text { Sorulara Verilen } \\
\text { Yanitların Ortalaması }\end{array}$ & $\mathbf{n}$ & $\overline{\mathbf{x}}$ & & \\
\hline $\begin{array}{l}\text { Öğrencilerin Hak ve } \\
\text { Sorumlulukları }\end{array}$ & 365 & 4,88 & & \\
\hline
\end{tabular}

Tablo 3'de soruların doğru şıkları renklendirilerek işaretlendirilmiştir. $\mathrm{Bu}$ tablodan da anlaşılacağı üzere öğretmen adaylarının verdiği doğru yanıtların ortalama puanının $\overline{\mathbf{X}}=\mathbf{4 , 8 8}$ olduğu, Öğrencilerin Hak ve Sorumlulukları ile ilgili bölümde bulunan 9 soru göz önünde bulundurulduğunda bu ortalamanın üzerinde olduğu görülmektedir.

Katılımcların temel eğitim hukuku bilgi düzeylerini belirlemek amacıyla yapılan 54 soruluk Temel Eğitim Hukuku Bilgi Testinin Disiplin Hukuku ile ilgili bölümünü 365 öğretmen adayı yanıtlamıştır. Elde edilen sonuçlar Tablo 4'de yer almaktadır:

Tablo 4'de soruların doğru şıkları renklendirilerek işaretlendirilmiştir. $\mathrm{Bu}$ tablodan da anlaşılacağı üzere ö öğretmen adaylarının verdiği doğru yanıtların ortalama puanının $\overline{\mathbf{X}}=\mathbf{2 , 4 9}$ olduğu, Disiplin Hukuku ile ilgili bölümde bulunan 8 soru göz önünde bulundurulduğunda bu ortalamanın düşük olduğu görülmektedir. Disiplin Hukuku alanındaki bilgi eksikliği öğretmen adaylarının göreve başladıklarında bir çok disiplin soruşturması ile karşı karşıya kalmaları riskini oluşturabileceği düşünülmektedir. Kamu hizmetlerinin düzgün bir şekilde yürütülmesi, işlerde aksama yaşanmaması ve mağduriyetlerin önüne geçilmesi için memur disiplin hukukuna yönelik bilgi sahibi olunması şarttır. 
Tablo 4. Öğretmen Adaylarının Disiplin Hukuku ile İlgili Sorulara Verdikleri Yanıtlar

\begin{tabular}{|c|c|c|c|c|}
\hline \multirow{2}{*}{ Disiplin Hukuku } & Doğru & Yanlış & Fikrim Yok & Toplam \\
\hline & n (\%) & n (\%) & n (\%) & $\mathrm{n}$ \\
\hline $\begin{array}{l}\text { 27) Bir y1lda toplam } 20 \text { gün ma- } \\
\text { zeretsiz olarak göreve gelmeyen } \\
\text { Murat öğretmenin memuriyeti } \\
\text { sona erer. }\end{array}$ & $129(\% 34,4)$ & $59(\% 15,7)$ & $187(\% 49,9)$ & 375 \\
\hline $\begin{array}{l}\text { 28) Adaylık süresi içinde hal ve } \\
\text { hareketlerinde memuriyetle } \\
\text { bağdaşmayacak durumları tespit } \\
\text { edilen öğretmenlerin görevine } \\
\text { hemen son verilmez ve asaleten } \\
\text { atanmaları beklenir. }\end{array}$ & $79(\% 21,2)$ & $105(\% 28,2)$ & $188(\% 50,5)$ & 372 \\
\hline $\begin{array}{l}\text { 29) Kınama cezası kendine tebliğ } \\
\text { edilen Kerem Öğretmen o gün } \\
\text { cezaya itiraz etmek zorundadır. }\end{array}$ & $80(\% 39,7)$ & $70(\% 22,2)$ & $225(\% 38,1)$ & 375 \\
\hline $\begin{array}{l}\text { 30) Aslı Öğretmen almış olduğu } \\
\text { kademe ilerlemesinin durdu- } \\
\text { rulması cezasını } 10 \text { yıl sonra } \\
\text { yetkili amire başvurarak özlük } \\
\text { dosyasından sildirebilir. }\end{array}$ & $81(\% 21,7)$ & $43(\% 11,5)$ & $249(\% 66,8)$ & 373 \\
\hline
\end{tabular}

31) 1. sinifta öğretmeninden

fiziksel şiddete maruz kalan

öğrenci durumu annesine 4. Sinıf-

tan mezun olduğunda anlatsa

bile, öğrencinin annesi; öğretmen

$188(\% 50,3) \quad 38(\% 10,2) \quad 148(\% 39,6) \quad 374$

hakkında şikayette bulunmak

suretiyle öğretmenin disiplin

cezası almasını sağlayabilir.

32) Suçun sabit olması durumunda öğretmenin savunması alınmadan da kendisine disiplin $53(\% 14,2) \quad 187(\% 50,1) \quad 133(\% 35,7)$

cezası verilir.

33) Kendisine haksız yere ceza verildiğini düşünen öğretmen, isterse kararın tebliğinden itibaren 60 gün içinde mahkemeye $212(\% 57,3) \quad 20(\% 5,4) \quad 138(\% 37,3) \quad 370$ itiraz başvurusunda bulunur.

34) Kendisine odada baş başayken hakaret eden okul müdürünün gizlice ses kaydını alan Tarık Öğretmen bunu müfettişe delil olarak sunabilir.

\begin{tabular}{lll}
\hline $\begin{array}{l}\text { Sorulara Verilen } \\
\text { Yanitların Ortalaması }\end{array}$ & $\mathbf{n}$ & $\overline{\mathbf{x}}$ \\
\hline Disiplin Hukuku & 365 & 2,49 \\
\hline
\end{tabular}


Katılımcların temel eğitim hukuku bilgi düzeylerini belirlemek amacıyla yapılan 54 soruluk Temel Eğitim Hukuku Bilgi Testinin Sınav Hukuku ile ilgili bölümünü 359 öğretmen adayı yanıtlamıştır. Elde edilen sonuçlar Tablo 5'te yer almaktadır:

Tablo 5. Öğretmen Adaylarının Sınav Hukuku ile İlgili Sorulara Verdikleri Yanıtlar

\begin{tabular}{|c|c|c|c|c|}
\hline \multirow{2}{*}{ Sinav Hukuku } & Doğru & Yanlış & Fikrim Yok & Toplam \\
\hline & n (\%) & n (\%) & n (\%) & $\mathrm{n}$ \\
\hline $\begin{array}{l}\text { 35) Sınav sonrası öğrencinin } \\
\text { sınav kâğıdını görme ve } \\
\text { inceleme hakkı vardır. }\end{array}$ & $299(\% 80,6)$ & $20(\% 5,4)$ & $52(\% 14,0)$ & 371 \\
\hline $\begin{array}{l}\text { 36) Sınav kâğıtları hazırlanırken } \\
\text { kâğıtta sadece öğrencinin adını } \\
\text { soyadını yazacağı bölüm ve sor- } \\
\text { uların olması yeterlidir. }\end{array}$ & $162(\% 43,9)$ & $136(\% 36,9)$ & $71(\% 19,2)$ & 369 \\
\hline $\begin{array}{l}\text { 37) Sınav sonuçları en geç bir ay } \\
\text { içinde öğrencilere duyurulur. } \\
\text { Acele etmeye gerek yoktur. }\end{array}$ & $58(\% 15,8)$ & $224(\% 61,0)$ & $85(\% 23,2)$ & 367 \\
\hline $\begin{array}{l}\text { 38) Kendisine düşük not verild- } \\
\text { iğini öne süren ilkokul öğrencisi } \\
\text { bizzat kendisi mahkemeye } \\
\text { başvurabilir. }\end{array}$ & $37(\% 10,1)$ & $207(\% 56,4)$ & $123(\% 33,5)$ & 367 \\
\hline $\begin{array}{l}\text { 39) Yazılı olarak yapılan } \\
\text { sınavların kağıtları herhangi bir } \\
\text { itiraz ve teftiş durumu için } 2 \text { yıl } \\
\text { arşivlenmek zorundadır. }\end{array}$ & $235(\% 64,2)$ & $31(\% 8,5)$ & $100(\% 27,3)$ & 366 \\
\hline $\begin{array}{l}\text { Sorulara Verilen } \\
\text { Yanitların Ortalaması }\end{array}$ & $\mathbf{n}$ & $\overline{\mathbf{X}}$ & & \\
\hline Sinav Hukuku & 359 & 2,99 & & \\
\hline
\end{tabular}

Tablo 5'te soruların doğru şıkları renklendirilerek işaretlendirilmiştir. $\mathrm{Bu}$ tablodan da anlaşılacağı üzere öğretmen adaylarının verdiği doğru yanitların ortalama puanının $\overline{\mathbf{X}}=2,99$ olduğu, Sınav Hukuku ile ilgili bölümde bulunan 5 soru göz önünde bulundurulduğunda bu değerin ortalamanın üzerinde olduğu görülmektedir.

Katılımciların temel eğitim hukuku bilgi düzeylerini belirlemek amacıyla yapılan 54 soruluk Temel Eğitim Hukuku Bilgi Testinin Özel Öğretim Hukuku ile ilgili bölümünü 356 öğretmen adayı yanıtlamıştır. Elde edilen sonuçlar Tablo 6'da yer almaktadır: 
Tablo 6. Öğretmen Adaylarının Özel Öğretim Hukuku ile İlgili Sorulara Verdikleri Yanitlar

\begin{tabular}{|c|c|c|c|c|}
\hline \multirow{2}{*}{ Özel Öğretim Hukuku } & Doğru & Yanlış & Fikrim Yok & Toplam \\
\hline & n (\%) & n (\%) & n (\%) & $\mathrm{n}$ \\
\hline $\begin{array}{l}\text { 40) Özel okulda görev yapan } \\
\text { Ayşe öğretmen en az devlet oku- } \\
\text { lunda görev yapan öğretmen ka- } \\
\text { dar maaş alır. }\end{array}$ & $62(\% 17,2)$ & $179(\% 49,7)$ & $119(\% 33,1)$ & 360 \\
\hline $\begin{array}{l}\text { 41) Özel öğretim kurumları } \\
\text { mevcutlarının en az \%3'ü kadar } \\
\text { ücretsiz öğrenci okutmak zorun- } \\
\text { dadır. }\end{array}$ & $118(\% 32,7)$ & $27(\% 7,5)$ & $216(\% 59,8)$ & 361 \\
\hline $\begin{array}{l}\text { 42) Özel öğretim kurumları } \\
\text { tazminat ödememek için ögrret- } \\
\text { menlerin görevine temmuzda } \\
\text { son verip eylülde tekrar işe } \\
\text { başlatırlar. }\end{array}$ & $96(\% 26,6)$ & $68(\% 18,8)$ & $197(\% 54,6)$ & 361 \\
\hline $\begin{array}{l}\text { 43) Özel okulda görev yapan } \\
\text { öğretmenin izin almadan veya } \\
\text { haklı bir sebep olmadan ard arda } \\
\text { iki iş günü işe gitmemekten } \\
\text { dolayı işine son verilebilir }\end{array}$ & $106(\% 29,2)$ & $57(\% 15,7)$ & $200(\% 55,1)$ & 363 \\
\hline $\begin{array}{l}\text { 44) Özel okulda görev yapan } \\
\text { Zehra Öğretmenin ücreti mücbir } \\
\text { sebep olmadan } 20 \text { günden fazla } \\
\text { geciktirilirse öğretmen artık } \\
\text { çalışmayabilir ve bu durumda } \\
\text { işten çıkartılamaz, yerine kimse } \\
\text { alınamaz. }\end{array}$ & $88(\% 4,4)$ & $42(\% 11,6)$ & $231(\% 64,0)$ & 361 \\
\hline $\begin{array}{l}\text { 45) Çok zengin bir işadamı olan } \\
\text { Ali Bey sahibi olduğu okulun } \\
\text { müdürü olmasa da eğitim } \\
\text { öğretim ve yönetim işlerine } \\
\text { müdahale etme hakkına sahiptir. }\end{array}$ & $35(\% 9,7)$ & $195(\% 54,0)$ & $131(\% 36,3)$ & 361 \\
\hline $\begin{array}{l}\text { Sorulara Verilen } \\
\text { Yanitların Ortalaması }\end{array}$ & $\mathbf{n}$ & $\overline{\mathbf{X}}$ & & \\
\hline Özel Öğretim Hukuku & 356 & 1,94 & & \\
\hline
\end{tabular}

Tablo 6'da soruların doğru şıkları renklendirilerek işaretlendirilmiştir. $\mathrm{Bu}$ tablodan da anlaşılacağı üzere öğretmen adaylarının verdiği doğru yanıtların ortalama puanının $\overline{\mathbf{X}}=\mathbf{1 , 9 4}$ olduğu, Özel Öğretim Hukuku ile ilgili bölümde bulunan 6 soru göz önünde bulundurulduğunda bu ortalamanın düşük olduğu görülmektedir.

Katılımcıların temel eğitim hukuku bilgi düzeylerini belirlemek amacıyla yapılan 54 soruluk Temel Eğitim Hukuku Bilgi Testinin Özel 
Eğitim Hukuku ile ilgili bölümünü 352 öğretmen adayı yanıtlamıştır. Elde edilen sonuçlar Tablo 7'de yer almaktadır:

Tablo 7. Öğretmen Adaylarını Özel Eğitim Hukuku ile İlgili Sorulara Verdikleri Yanitlar

\begin{tabular}{|c|c|c|c|c|}
\hline \multirow{2}{*}{ Özel Eğitim Hukuku } & Doğru & Yanlış & Fikrim Yok & Toplam \\
\hline & n (\%) & n (\%) & n (\%) & $\mathrm{n}$ \\
\hline $\begin{array}{l}\text { 46) Dört yaşında olan Fur- } \\
\text { kan'ın ailesi, çocuklarının özel } \\
\text { eğitime ihtiyacı olduğunu } \\
\text { bilseler bile onu evde eğitebil- } \\
\text { irler. Okul öncesi eğitim Fur- } \\
\text { kan için zorunlu değildir. }\end{array}$ & $70(\% 19,3)$ & $188(\% 51,9)$ & $104(\% 28,7)$ & 362 \\
\hline $\begin{array}{l}\text { 47) Kaynaştırma öğrencisine } \\
\text { hiçbir surette sınıf tekrarı } \\
\text { yaptırılmaz. }\end{array}$ & $93(\% 25,7)$ & $117(\% 32,3)$ & $152(\% 42,0)$ & 362 \\
\hline $\begin{array}{l}\text { 48) BEP (Bireyselleştirilmiş } \\
\text { Eğitim Programı) sadece üs- } \\
\text { tün yetenekli çocuklar için } \\
\text { hazırlanır. }\end{array}$ & $50(\% 13,9)$ & $204(\% 56,7)$ & $106(\% 29,4)$ & 360 \\
\hline $\begin{array}{l}\text { 49) Bir sınıfta en fazla } 3 \\
\text { kaynaştırma öğrencisi olabilir. }\end{array}$ & $154(\% 43,0)$ & $52(\% 14,5)$ & $152(\% 42,5)$ & 358 \\
\hline $\begin{array}{l}\text { Sorulara Verilen } \\
\text { Yanitların Ortalaması }\end{array}$ & $\mathbf{n}$ & $\overline{\mathbf{X}}$ & & \\
\hline Özel Eğitim Hukuku & 352 & 1,56 & & \\
\hline
\end{tabular}

Tablo 7'de soruların doğru şıkları renklendirilerek işaretlendirilmiştir. $\mathrm{Bu}$ tablodan da anlaşılacağ 1 üzere öğretmen adaylarının verdiği doğru yanıtların ortalama puanının $\overline{\mathbf{X}}=\mathbf{1 , 5 6}$ olduğu, Özel Eğitim Hukuku ile ilgili bölümde bulunan 4 soru göz önünde bulundurulduğunda bu değerin düşük olduğu görülmektedir.

Katılımcıların temel eğitim hukuku bilgi düzeylerini belirlemek amacıyla yapılan 54 soruluk Temel Eğitim Hukuku Bilgi Testinin Kamu Okullarının Finansmanı ile ilgili bölümünü 357 öğretmen adayı yanıtlamıştır. Elde edilen sonuçlar Tablo 8'de yer almaktadır:

Tablo 8'de soruların doğru şıkları renklendirilerek işaretlendirilmiştir. $\mathrm{Bu}$ tablodan da anlaşılacağı üzere 16 ' da öğretmen adaylarının verdiği doğru yanitların ortalama puanının $\overline{\mathbf{X}}=\mathbf{2 , 3 7}$ olduğu, Kamu Okullarının Finansmanı ile ilgili bölümde bulunan 5 soru göz önünde bulundurulduğunda bu değerin ortalamanın altında kaldığı görülmektedir. 
Tablo 8. Öğretmen Adaylarının Kamu Okullarının Finansmanı ile İlgili Sorulara Verdikleri Yanitlar

\begin{tabular}{|c|c|c|c|c|}
\hline \multirow{2}{*}{ Kamu Okullarının Finansmanı } & Doğru & Yanlış & Fikrim Yok & Toplam \\
\hline & n (\%) & n (\%) & n (\%) & $\mathrm{n}$ \\
\hline $\begin{array}{l}\text { 50) Okul Müdürü velileri } \\
\text { bankaya kadar yormamak için } \\
\text { Okul Aile Birliğine yapılan } \\
\text { bağışları elden alabilir. Okul } \\
\text { kasasında biriken paralar sene } \\
\text { sonunda bankaya yatırılır. }\end{array}$ & $82(\% 22,8)$ & $128(\% 35,6)$ & $150(\% 41,7)$ & 360 \\
\hline $\begin{array}{l}\text { 51) Okul Aile Birliğine ait banka } \\
\text { hesabındaki paranın okul } \\
\text { müdürü tarafından çekilme- } \\
\text { sinde bir sakınca yoktur. }\end{array}$ & $44(\% 12,2)$ & $175(\% 48,5)$ & $142(\% 39,3)$ & 361 \\
\hline $\begin{array}{l}\text { 52) Okul müdürü kantini uygun } \\
\text { gördüğü herhangi birine } \\
\text { kiralayabilir. }\end{array}$ & $72(\% 19,9)$ & $177(\% 48,9)$ & $113(\% 31,2)$ & 362 \\
\hline $\begin{array}{l}\text { 53) Okul Aile Birliklerin, okulun } \\
\text { hizmetli ihtiyacını karşılaya- } \\
\text { bilmek için velileri bağış yap- } \\
\text { maya zorlar ve okul kayıt döne- } \\
\text { minde bağ }{ }_{1 S ̧} \text { ve yardım toplar. }\end{array}$ & $69(\% 19,0)$ & $200(\% 55,1)$ & $94(\% 25,9)$ & 363 \\
\hline $\begin{array}{l}\text { 54) Okul öncesi eğitimde } \\
\text { çocukların beslenme, temizlik } \\
\text { hizmetleri ve eğitim pro- } \\
\text { gramının uygulanmasına } \\
\text { yönelik eğitim materyalleri için } \\
\text { ücret alınır. }\end{array}$ & $177(\% 49,0)$ & $69(\% 19,1)$ & $115(\% 31,9)$ & 361 \\
\hline $\begin{array}{l}\text { Sorulara Verilen } \\
\text { Yanitların Ortalaması }\end{array}$ & $\mathbf{n}$ & $\overline{\mathbf{X}}$ & & \\
\hline Kamu Okullarının Finansmanı & 357 & 2,37 & & \\
\hline
\end{tabular}

\section{Tartışma ve Sonuç}

Öğretmen adaylarının temel eğitim hukuku bilgi düzeylerini belirlemek amacıyla yapılan 54 soruluk Temel Eğitim Hukuku Bilgi Anketini 386 öğretmen adayı cevaplamıştır. Sorulara verilen yanıtlar değerlendirildiğinde; "öğretmenlerin hak ve sorumlulukları", "disiplin hukuku”, "özel öğretim hukuku", "özel eğitim hukuku" ve "kamu okullarının finansmanı" ile ilgili bölümlerinde bulunan sorulara verilen doğru cevap ortalamalarının düşük olduğu görülmektedir.

Karaman Kepenekçi (2004) "İlköğretim Okulu Yöneticilerinin Eğitim Mevzuatına Iliş̧kin Görüşleri" başlıklı çalışmasında; katılımcıların görüşlerine göre eğitim mevzuatının başta yöneticiler olmak üzere öğretmenler, 
veliler ve hatta öğrenciler tarafından bilinmediğini ve eğitim mevzuatını uygulamada karşılaşılan sorunların büyük ölçüde bu eksiklikten kaynaklandığ1 sonucuna ulaşmıştır. Cereci (2009) ise "Kamu İlk Ve Orta Öğretim Okullarında Çalş̧an Öğretmenlerin Özlük Haklarımı Bilme Ve Kullanma Düzeyleri" adlı çalışmasında; öğretmenlerin eğitim düzeyi yükseldikçe özlük hakların bilme düzeylerinin de yükseldiği, yüksek lisans mezunu öğretmenlerin, ön lisans ve lisans mezunu öğretmenlere göre özlük haklarını daha yüksek düzeyde bildikleri, lisans mezunu öğretmenlerin de ön lisans mezunu öğretmenlere göre özlük haklarını daha fazla bildikleri sonucuna ulaşmıştır. Güçlü Yılmaz (2017) çalışmasında eğitim hukuku bilen avukatlara olan ihtiyaca dikkat çekmiş ve eğitim sisteminde yeni düzenlemeler yapan yönetmeliklerin de düzenleme yapılan alan ile ilgili kanunlara uygunluklarının eğitimcilerin ve hukukçuların takibinde olmasını savunarak, Eğitim Hukuku gibi bu alana yönelik derslerin Hukuk ve Eğitim Fakültelerinde okutulmasını savunmuştur (s. 384).

Öğretmen adaylarının "Eğitim Yönetimi" veya "Türk Eğitim Sistemi ve Okul Yönetimi” derslerini almış üçüncü ve son sınıf öğrencileri arasından seçilmiş olmaları göz önünde bulundurulduğunda, bu derslerin müfredatının eğitim hukuku ile ilgili müfredattan farklı olduğu ve bu nedenle öğretmen adaylarının bu dersleri almış olmalarının eğitim hukuku ile ilgili bilgi düzeylerine çok fazla bir olumlu etkisinin olmadığ söylenebilir. YÖK (2018b) tarafından yayımlanan ve 2018-2019 eğitimöğretim yılında eğitim fakülteleri birinci sınıfa başlayacak öğretmenlere uygulanacak yeni öğretmen yetiştirme lisans programları incelendiğinde de "Eğitim Yönetimi", "Türk Eğitim Sistemi ve Okul Yönetimi" ile "Eğitim Hukuku" derslerinin içeriğinin çok farklı olduğu anlaşılmaktadır.

Literatürde "öğretmenlerin hak ve sorumlulukları" ile ilgili bölüm ile ilgili olarak bu araştırma sonucunu destekleyen veya desteklemeyen araştırma örnekleri mevcuttur. Erdem (2010) tarafından yapılan araştırmada; ilköğretim ve ortaöğretim öğretmenleri özlük sorunlarına katılmada en önemli sorunu "öğretmenin özlük haklarını tam olarak bilmemesi ve özlük haklarının yeterince öğretmenlere anlatılmaması"; olarak değerlendirmişlerdir. Ancak Cereci (2009) tarafından yapılan kamu ilk ve orta öğretim okullarında çalışan öğretmenlerin özlük haklarını bilme düzeylerini amaçlayan araştırmanın sonuçları ile bu araştırmanın sonuçları farklılık göstermektedir. Bahsi geçen araştırmada öğretmenlerin 
özlük haklarını bilme düzeylerinin ortalamanın üzerinde olduğu ve kıdemi 11 yıl ve daha fazla olan öğretmenlerin bilgi düzeylerinin daha yüksek olduğu sonucuna ulaşılmıştır. Her ne kadar literatür aynı yönde görüş ortaya koymasa da öğretmenlerin hak ve sorumluluklarını bilme ihtiyaçları görmezden gelinmemelidir. Ya da bu eğitimlerin aday öğretmen yetiştirilmesi sürecinde Milli Eğitim Bakanlığı tarafından verilmesi beklenmemelidir. Unutulmamalıdır ki öğretmen bir kamu kurumuna atandığ1 kendisine ilk tebliğ edildiği andan itibaren sorumluluk altına girmektedir. Göreve başlama süresi, yolluk alıp almayacağı, eğitim öğretim ödeneğinden faydalanıp faydalanmayacağı gibi durumlarla aday eğitiminden önce karşılaşılmaktadır. Bu nedenle göreve başlamadan önce üniversitelerde verilecek bir eğitim ile öğretmenlerin bu alandaki eğitim ihtiyaçlarının giderilmesi gerekmektedir.

Öğretmen adaylarının disiplin hukuku ile ilgili bölümlerde bulunan sorulara verilen doğru cevap ortalamalarının düşük olması da bu alanda eğitim ihtiyacının olduğunu göstermektedir. Bu husus ile ilgili olarak atılmış olumlu bir adımdan burada bahsetmek gerekir. 2014 yılındaki değişikliğe kadar öğretmenleri ilgilendiren disiplin mevzuatında birkaç farklı kanunun olması nedeniyle karışıklıklar yaşanmıştır. Bu karışıklıkların önüne geçmek için 1702 sayılı Kanun ile 4357 sayılı Kanunun disiplin hükümleri 14/03/2014 tarihli ve 28941 sayılı Resmi Gazetede yayımlanan Milli Eğitim Temel Kanunu ile Bazı Kanun ve Kanun Hükmünde Kararnamelerde Değişiklik Yapılmasına Dair 6528 sayılı Kanun ile yürürlükten kaldırılmıştır. Bu gelişme sonrası öğretmenleri ilgilendiren disiplin hükümleri sadeleşmiştir. Üniversitelerde verilecek bir disiplin hukuku eğitiminde bu durum eğitim verenlerin işini kolaylaşmasını sağlayacak bir avantaj olarak düşünülebilir. Yukarda da tekrar edildiği gibi eğitimlerin aday öğretmen yetiştirilmesi sürecinde Milli Eğitim Bakanlığı tarafından verilmesi beklenmemelidir. Yaşanabilecek bir gecikme nedeniyle öğretmenlerin disiplin soruşturması geçirip ceza almasını engelleyecek önlemler alınması gerekmektedir.

“Özel öğretim hukuku" ile ilgili bölümlerde bulunan sorulara verilen doğru cevap ortalamalarının düşük olması, öğretmen adaylarının özel sektör ile ilgili bilgilerinin yetersiz olduğunu göstermektedir. Ancak öğretmen adaylarının sadece kamu alanında istihdam edilmediği ve özel 
sektörde çalışmak zorunda kaldıkları gerçeği göz önünde bulundurulduğunda hak kaybına uğramamaları için bu alanda eğitim almaları gerekmektedir. Örneğin Yılmaz ve Altınkurt (2011) tarafından yapılan bir araştırmada hizmet süresi 5 yıl veya daha az olan ve özel öğretim kurumlarında çalışan öğretmenlerin çalışma koşulları ile ilgili görüşlerine başvurulmuş ve bu öğretmenlerin genel olarak ilk tercihlerinin buralarda çalışmak olmadığı, çalışma koşullarının çok zor ve ağır olduğu, bundan olumsuz etkilendikleri, aldıkları ücretin ise emeklerinin karşılığı olmadığı sonucuna ulaşılmıştır. Boran, Atalmış ve Sağır (2015)'ın yapmış olduğu araştırmada da benzer sonuçlara ulaşılmış ve özel öğretim kurumlarında çalışan öğretmenlerin yönetim ile problem yaşadıkları, zaman yönetimi, özlük haklarının ihlali ve maaş gibi konularda sorunlarının olduğu tespit edilmiştir. Bu sonuçlardan da anlaşılacağı üzere özel öğretim hukuku ile ilgili bilgi yetersizliği olan öğretmenler, özel sektörde çalışmaları durumunda birçok sıkıntı ile karşılaşabileceklerdir. Bu sorunlarla mücadele edebilmeleri ise mevzuat ile kendilerine tanınan hakların neler olduğunu iyi bilmelerini gerektirmektedir. Özel sektörde mevzuat uygulamalarına yönelik aday öğretmenlere verilecek zorunlu bir hizmetiçi eğitim programı olmaması nedeniyle bu eğitimin üniversitelerde verilmesi gerekmektedir

"Özel eğitim hukuku" ilgili bölümlerde bulunan sorulara verilen doğru cevap ortalamalarının düşük olması nedeniyle bu konu ile ilgili olarak öğretmen adaylarının eğitime ihtiyacı olduğu yorumu yapılabilir. Aker (2014) tarafından yapılan bir araştırmada öğretmen adaylarının kaynaştırma eğitimi dersi veya özel eğitimle ilgili başka bir ders alması durumunda kaynaştırmaya yönelik tutumlarının daha olumlu olduğu sonucuna ulaşılmıştır. Gözün ve Yıkmış (2004)'ın yapmış olduğu araştırmada da benzer sonuçlara ulaşılmış ve kaynaştırmaya yönelik bilgilendirme programına katılan öğretmen adaylarının kaynaştırmaya yönelik tutumlarının olumlu etkilendiği sonucuna ulaşılmıştır. Yine bu sonuçları destekleyen bir başka araştırmada Camadan (2012) tarafından hizmet içi eğitim alan öğretmenlerin, almayan öğretmenlere göre kaynaştırma eğitimine ve BEP (Bireyselleştirilmiş Eğitim Programı) hazırlamayla ilgili kendilerini daha yeterli algıladıkları sonucuna ulaşılmıştır. 
Öğretmen adaylarının "kamu okullarının finansmanı" ile ilgili bölümdeki sorulara verdiği doğru cevapların ortalamasının da düşük olması bu alanda eğitim ihtiyacını gösterir bir sonuçtur. Göreve yeni başlayan öğretmenlerin zorunlu hizmet bölgelerinde müdür yetkili öğretmen veya tek öğretmen olarak göreve başlayabilecekleri ihtimali göz önünde bulundurulduğunda bu alanda donanımlı olarak göreve başlamaları gerekmektedir.

"Temel eğitim hukuku" ile ilgili bölümdeki sorulara cevap veren öğretmen adaylarının "öğrencilerin hak ve sorumlulukları" ve "sınav hukuku" ile ilgili bölümlerinde bulunan sorulara verilen doğru cevap ortalamalarının ise nispeten yüksek olduğu ancak eğitim alma hakkı ve eğitime devamın sağlanması, öğrencilerin kılık kıyafetleri ve sınav kağıtlarının hazırlanmasına yönelik sorularda verilen doğru cevap ortalamalarının ise düşük olduğu görülmüştür. "Öğrencilerin hak ve sorumlulukları" konusu çağdaş yönetim anlayışı gereği bu konunun muhatapları tarafından bilinmeli ve eğitim hizmeti gerçekleştirilirken bu hak ve sorumluluklara uygun bir tutum sergilenmelidir. Aydın (2006)'ya göre bu haklar kaynağını önce insan haklarından, daha sonra çocuk haklarından ve son olarak da öğrenci kimliklerinin getirdiği yeni rollerinden almaktadır (s.150). Öğretmen adaylarının "öğrenci hak ve sorumlulukları" na yönelik bilgi düzeylerinin ortalamanın üzerinde olması olumlu bir sonuç olarak değerlendirilmiştir. Konu ile benzer özellikler taşıyan bir başka araştırmada Uçuş ve Şahin (2012) tarafından öğretmenlerin ve okul yöneticilerinin çocuk hakları konusunda yeterince bilgiye sahip olmadığı sonucuna ulaşılmıştır. Çocuk Hakları Sözleşmesi eğitim hakkı ile ilgili düzenlemeleri de içerdiğinden iki araştırmanın sonuçlarının birbirini destekler nitelikte olduğu yorumu yapılabilir. Ayrıca Eğitim Fakültelerinde uygulanan müfredat kapsamında öğretmen adaylarının ölçme değerlendirme dersini zorunlu alıyor olmaları ve yıllardır sınavların hakim olduğu bir sistemde eğitimde yetişmeleri sınav hukuku ile ilgili bilgi düzeylerinin yüksek olmasına bir sebep gösterilebilir.

$\mathrm{Bu}$ araştırmada elde edilen sonuçlar doğrultusunda öğretmen adaylarının eğitim hukuku ile ilgili eğitim ihtiyaçlarının giderilmesine yönelik şu öneriler getirilebilir:

- Eğitim hukuku dersinin lisans düzeyinde zorunlu ders olarak müfredata alınmasıyla öğretmen adaylarının bu alanda görülen bilgi 
eksikliklerinin giderilmesi, meslek hayatlarında karşılarına çıkabilecek farklı durumlarla mücadele edebilme becerileri kazandırılabilir.

- Eğitim hukuku ülkemizde henüz gelişmekte olan bir alan olduğu için hukuk fakülteleri ile işbirliği yapılarak bir müfredat oluşturulması ve oluşturulacak müfredatın yoğunluğu nedeniyle dersin iki döneme yayılması sağlanabilir.

- Özel sektörde görev yapacak öğretmenler için özel öğretim hukukunu temel alan bir hazırlayıcı eğitim programı düzenlenerek öğretmenlerin bu eğitimi aldıktan sonra özel sektörde görev yapması sağlanabilir. 


\title{
EXTENDED ABSTRACT
}

\section{Determination of the Educational Needs of Teacher Candidates Related to Educational Law}

\author{
* \\ Müzeyyen Övür - Faruk Levent \\ Marmara University
}

While education was previously an elite privilege, it became a need for every segment of society. This need has been tried to be met by personal means for a long time. However, with the adoption of compulsory and free education for all, the need for education was met by the state and this was guaranteed by international conventions. This is the reason why various national and international regulations have been made in many parts of the world to ensure that everyone is entitled to education. These regulations, which concern both education and law, paved the way for the emergence of a new discipline called Education Law (Okçu, 2007, p. 57). Law is a singular and plural word. Law is a plural form of right, which is actually an Arabic word, made according to the Arabic grammar. However, in time, it began to be used in plural form with a meaning other than the expression and thus developed into a singular word in Turkish (Özyörük, 1959, p. 31). Therefore, all rights in the field of education can be called education law. By the definition of educational law, it is basically a wide area; Rights and Responsibilities of Education Stakeholders, Disciplinary Law, Examination Law, Higher Education Law, Private Education Law, Private Education Law, Public Schools and Other Educational Institutions. When it comes to educational law, examining and interpreting only the legal texts in force related to education can simplify the subject and cause it to be under-understood. It is not the right approach to limit the subject of educational law to the rights of teachers and students. In fact, it is not technically possible to examine all legal texts related to education, since the education is related to many legislation. Considering that there are limited number of narrow-scale studies on this subject in our country, it is necessary to examine the subject with an interdisciplinary 
approach in a unique way. Pre-service teachers have different courses during their undergraduate education and they are based on the teaching profession with their formation training. However, their ability to transfer this knowledge to their professional lives can bring certain problems. In particular, the transition process between theory and practice is not easy and unintentional serious mistakes can be made due to lack of knowledge. This lack of knowledge in the field of educational law causes teachers and administrators to drift towards a conclusion ending with administrative and even forensic investigations. It can be said that due to insufficient knowledge about the subject, they suffered loss of rights, could not defend their rights adequately, and there was a lack of information on child rights and suffered from grievances. The possibility of loss of rights due to the lack of special training in this field should not be ignored in the courts opened on education-related issues. Disciplinary law, exam law, school financing, students' rights and responsibilities, special education and special education law areas, such as the lack of a single course can be felt under one roof. For this reason, it is of utmost importance that the law of education is included in the curriculum as a compulsory course at the undergraduate level to eliminate the lack of knowledge of prospective teachers and to gain the ability to combat different situations in their professional lives. Many Western countries, recognizing the importance of this, have included the subject into their curricula and have created their conceptual frameworks related to their own educational legislation and contributed to the field of educational law. It can be said that although the field of educational law in our country has not gained a place in the faculties of law, it is only included in the elective course category as an undergraduate course in the field of educational sciences and it is included in the programs of some universities. In addition, when the related literature is examined, it is thought that the study is original and will contribute to the literature in a different way if it is considered that no such study has been done about education law before and other studies have not used an action research method for the solution process 
The purpose of this study was to determine the educational needs of teacher candidates related about basic education law. In this study, screening model which is one of the quantitative research methods was used. The sample group of the study consisted of 386 teacher candidates from 3rd and 4th grade students who are studying at Marmara University and who took "Education Management" or "Turkish Education System and School Management" courses. As a data collection tool, 54-item Knowledge Level Determination Questionnaire on Educational Law tarafından was prepared by the researchers to determine the level of knowledge of prospective teachers about basic education law. Percentage, frequency and arithmetic mean tests were performed to analyze the collected data.

According to the findings; "Rights And Responsibilities Of Teachers", "Disciplinary Law", "Private Teaching Law" "Special Education Law" and "Financing Public Schools" It was found that the average of the correct answers given to the questions in the related sections were low. Rights And Responsibilities Of Students" and "Exam Law" it was found that the average of the correct answers to the questions found in the relevant sections of the study was high. But "Right to Education" "Ensuring Continuation of Education", "Students' Costumes" and "Preparation of Examination Papers" it was found that the average of the correct answers to the questions about the low. In line with the results obtained in this study, it is suggested that the Education Law course should be included in the curriculum as a compulsory course at the undergraduate level in order to meet the educational needs of prospective teachers regarding education law. Thus, by eliminating the information deficiencies of the prospective teachers in this field, they can gain the skills to combat different situations in their professional lives.

\section{Kaynakça / References}

Aker, G. (2014). Öğretmen adaylarının kaynaştırma eğitimi hakkındaki tutumları. Yayınlanmamış yüksek lisans tezi, Trakya Üniversitesi Sosyal Bilimler Enstitüsü, Edirne.

Akyüz, E. (1981). Ĕgitim hukuku ders notu. Ankara: Ankara Üniversitesi Eğitim Fakültesi Eğitim Araştırmaları Merkezi. 
Aydın, İ. (2006). Eğitim ve öğretimde etik. Ankara: PegemA Yayıncılık.

Bademci, V. (2011). Kuder-Richardson 20, Cronbach'ın Alfası, Hoyt'un varyans analizi, genellenirlik kuramı ve ölçüm güvenirliği üzerine bir çalışma, Dicle Üniversitesi Ziya Gökalp Ĕ̆itim Fakültesi Dergisi, 1, 173193.

Bingöl, B. (2012). Türkiye için bir eğitim hukuku teorisinin gerekliliği, Hacettepe Üniversitesi Hukuk Fakültesi Dergisi, 2, 25-38.

Boran, A., Atalmış, E. H. ve Sağır, E. (2015). Özel öğretim kurs merkezi öğretmenleri ve çalışma koşulları. Turkish Journal of Education TURJE, 4(4), 17-29.

Büyüköztürk, Ş. (2005). Sosyal bilimler için veri analizi el kitabı. Ankara: PegemA Yayıncilik.

Camadan, F. (2012). Sınıf öğretmenleri ve sınıf öğretmeni adaylarının kaynaştırma eğitimine ve bep hazırlamaya ilişkin özyeterliklerinin belirlenmesi. Elektronik Sosyal Bilimler Dergisi, 11(39), 128-138.

Cereci, C. (2009). Kamu ilk ve orta öğretim okullarında çalışan öğretmenlerin özlük hakların bilme ve kullanma düzeyleri:Mersin ili Tarsus ilçesi örneği. Yayınlanmamış yüksek lisans tezi, Ankara Üniversitesi Sosyal Bilimler Enstitüsü.

Çiftçi, A. (1993). Türk eğitim hukuku. Ankara: Dizgi Bask1.

Erdem, A. R. (2010). İlköğretim ve ortaöğretim öğretmenlerinin karşılaştı̆̆1 özlük sorunları ve bu özlük sorunlarının performanslarına etkisi konusundaki görüşleri. Adnan Menderes Üniversitesi Ĕ̆itim Fakültesi Ĕ̆itim Bilimleri Dergisi, 1(1), 21-55.

Gözün, Ö. ve Yıkmış, A. (2004). Öğretmen adaylarının kaynaştırma konusunda bilgilendirilmelerinin kaynaştırmaya yönelik tutumlarının değişimindeki etkililiği. Ankara Üniversitesi Ĕ̆̈itim Bilimleri Fakültesi Özel Ĕ̈itim Dergisi, 5(2), 65-77.

Güçlü-Yılmaz, F. (2017). Güçlü bir hukuk devleti için etik, demokratik, laik eğitim sistemi ve eğitim hukuku. Türkiye Barolar Birliği Dergisi. 347388.

Georgetown Üniversitesi. (2019). Education law. 10/05/2019 tarihinde adresinden https://www.law.georgetown.edu/your-life-career/ca-reer-exploration-professional-development/for-jd-students/explore-legalcareers/practice-areas/education-law/ adresinden erişilmiştir. 
Ahearn, D. ve Powers, T. (2014). Education law: A Career Guide. 10/05/2019 tarihinde https://hls.harvard.edu/content/uploads/2008/07/-2015_educationlawguide_final.pdf adresinden erişilmiştir.

Imber, M., Van Geel, T., Blokhuis, J.C. ve Feldman J. (2013). A teacher's guide to education law. (5th ed). New York: Routledge.

Karaman-Kepenekçi Y. ve Taşkın, P. (2017). Ĕ̆itim hukuku. Ankara: Siyasal Kitabevi.

Karaman-Kepenekçi, Y. (2004). İlköğretim okulu yöneticilerinin eğitim mevzuatına ilişkin görüşleri. Eğitim Bilimleri ve Uygulama, 3(6), 159-174.

MEB. (2018) Milli Ĕğitim İstatistikleri. 12/06/2019 tarihinde https://sgb.meb.gov.tr/www/icerik_goruntule.php?KNO=270 adresinden erişilmiştir.

Okçu, D. (2007). Eğitim hakkı ve tarihsel gelişimi. Yüzüncü yıl üniversitesi, Eğitim Fakültesi Dergisi, 4(1), 45-59.

Şişman, M. ve Turan, S. (2002). Dünyada eğitim yöneticilerinin yetiştirilmesine ilişkin başlıca yönelimler ve Türkiye için çıkarılabilecek bazı sonuçlar. 21. Yüzyıl Eğitim Yöneticilerinin Yetiştirilmesi Sempozyumu, Ankara : Ankara Üniversitesi Eğitim Bilimleri Fakültesi Yayınları.

Uçuş Ş. ve Şahin, A. E. (2012). Çocuk hakları sözleşmesi'ne yönelik öğretmenlerin ve okul yöneticilerinin görüşleri. Adnan Menderes Üniversitesi Eğitim Fakültesi Ĕ̆itim Bilimleri Dergisi, 3(1), 25-41.

Yıldırım, A. ve Şimşek, H. (2011). Sosyal bilimlerde araştırma yöntemleri. Ankara: Seçkin Yayıncılık.

Yılmaz, K. ve Altınkurt, Y. (2011). Göreve yeni başlayan özel dershane öğretmenlerinin kurumlarındaki çalışma koşullarına ilişkin görüşleri. $\mathrm{Ku}$ ram ve Uygulamada Ĕ̆itim Bilimleri, 11(2), 635-650.

YÖK. (2018a). Programlarm güncelleme gerekçeleri, getirdiği yenilikler ve uygulama esaslart. 21.12.2018 tarihinde https://www.yok.gov.tr/-Documents/Kurumsal/egitim_ogretim_dairesi/Yeni-Ogretmen-YetistirmeLisans-Programlari/AA_Sunus_\%20Onsoz_Uygu-lama_Yonergesi.pdf adresinden erişilmiştir.

YÖK. (Yükseköğretim Kurulu). (2018b). Yeni öğretmen yetiştirme lisans programlarl. 21.12.2018 tarihinde https://www.yok.gov.tr/Documents/Kurumsal/egitim_ogretim_dairesi/Yeni-Ogretmen-Yetistirme-LisansProgramlari/Rehberlik_ve_Psikolojik_Danismanlik_Lisans_Prog rami.pdf adresinden erişilmiştir. 
1739 Sayılı Milli Eğitim Temel Kanunu (Haziran 24, 1973). Resmi Gazete. No:14574.

6528 sayılı Millî Eğitim Temel Kanunu İle Bazı Kanun Ve Kanun Hükmünde Kararnamelerde Değişiklik Yapılmasına Dair Kanun. (2014). Resmi Gazete. Ankara.

\section{Kaynakça Bilgisi / Citation Information}

Övür, M. ve Levent, F. (2019). Öğretmen adaylarının eğitim hukuku ile ilgili eğitim ihtiyaçlarının belirlenmesi. OPUS-Uluslararası Toplum Araştırmaları Dergisi, 13(19), 454-480. DOI: 10.26466/opus.594809 